
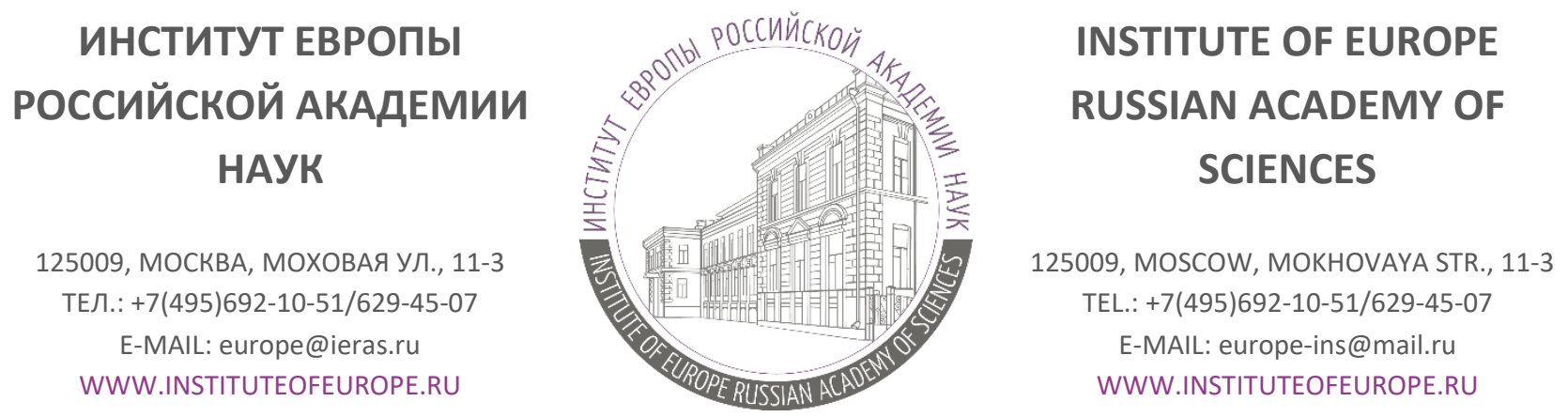

Аналитическая записка №38, 2020 (№221) ${ }^{1}$

\title{
Вторая волна пандемии в Чехии: первые политические последствия
}

\begin{abstract}
Михаил Владимирович Ведерников
кандидат исторических наук, старший научный сотрудник Отдела исследований Центральной и Восточной Европы Института Европы РАН
\end{abstract}

\begin{abstract}
Аннотация. 21 сентября 2020 года в Чехии на фоне роста вылвленных случаев заболевания COVID19 произошла отставка министра здравоохранения А. Войтеха. Очевидно, такая мера была вызвана желанием руководства страны взвалить вину на конкретного человека. Впрочем, событие является также одним из элементов текущей предвыборной кампании в муниципальные органы власти $u$ Сенат. Движение премьера А. Бабиша АНО, которое в предшествуюшее время не смогло удачно выступить на выборах этого уровня, в нынешней электоральной кампании заинтересовано 8 повышении поддержки со стороны избирателей. На фоне падения его популярности отставка Войтеха, которого стали обвинять в обострении эпидемиологической ситуачии, должна была подтвердить позитивный образ правительства Бабиша, готового идти на компромисс $u$ прислушиваться к мнению как оппозищии, так и населения в целом.
\end{abstract}

Ключевье слова: коронакризис, пандемия, Чехия, Центральная Европа, А. Бабиш, А. Войтех.

\section{Вторая волна пандемии в Центральной Европе}

В сентябре 2020 г. количество заболевших коронавирусом COVID-19 в странах Центральной Европы начало стремительно увеличиваться. За период с 10 по 20 сентября количество инфицированных в государствах Вишеградской группы стало наивысшим за всю эпидемию. За 1 день в Словакии было зафиксировано 290 случаев заражения, Польше - 1 002, Венгрии -

\footnotetext{
${ }^{1}$ DOI: http://doi.org/10.15211/analytics382020
} 
1070 , Чехии - 3 129. На фоне отметки в 31 млн больных в мире, это, конечно, немного, но следует учесть, что в период т.н. первой волны пандемии эти страны показали наилучший пример борьбы с коронавирусом в Европе, не допустив его взрывного распространения, как было, например, в Испании и Италии. Дневные показатели в странах Вишеграда составляли тогда лишь десятки и сотни заболевших на фоне тысяч в упомянутых южноевропейских государствах. Этот факт дал повод экспертам говорить об особой, центральноевропейской модели предотвращения болезни и необходимости учета их полезного опыта. Осенью, когда страны Западной Европы уже научились держать вирус «под контролем», вишеградские государства вновь громко заявили о себе, первыми забив тревогу о новой волне пандемии. Количество заболевших по сравнению с предельными уровнями весны многократно выросло: в Польше и Словакии примерно в 3 раза, в Венгрии - в 5, в Чехии - практически в 10 раз.

\section{Коронакризис в Чехии}

В весенние месяцы 2020 г. внимание мировой общественности было приковано к действиям властей Чехии, которым удалось успешно преодолеть первую волну пандемии. Как внутри страны, так и за её пределами широко обсуждалась обоснованность введения 66-дневного чрезвычайного положения и строгость ограничений. Страна одной из первых закрыла сухопутные и воздушные границы, изолировавшись от соседей по ЕС, ввела обязательства по ношению защитных масок и перчаток не только в общественном транспорте и помещениях, но и на открытом пространстве; ввела существенные штрафы за нарушение карантина. Тогда эти меры вызвали бурную дискуссию: например, правительство Нидерландов опубликовало заявление, к которому присоединились еще 18 стран-участниц $\mathrm{EC}$, за исключением представителей вишеградской «четверки». В нем была выражена обеспокоенность по поводу возможных рисков нарушения верховенства права, демократии и фундаментальных прав из-за введения чрезвычайных мер в отдельных странах $\mathrm{EC}^{2}$. А Председатель Еврокомиссии У. фон дер Ляйен обвинила Чехию в посягательстве на шенгенские достижения ${ }^{3}$.

Сопротивление принятым мерам имело место и внутри самой Чехии. Это привело к тому, что некоторые журналисты либерального толка называли сложившийся в период пандемии строгий порядок «коронадиктатурой» и «коронафашизмом» ${ }^{4}$. Несмотря на критику, методы, применяемые чешским правительством, были на тот момент эффективны и обезопасили чехов от массового заражения.

\footnotetext{
${ }^{2}$ Statement by Belgium, Bulgaria, Cyprus, Denmark, Estonia, Finland, France, Germany, Greece, Ireland, Italy, Latvia, Lithuania, Luxembourg, the Netherlands, Portugal, Romania, Spain, Sweden. Government of the Netherlands. 01.04.2020. URL: https://www.government.nl/documents/diplomatic-statements/2020/04/01/statement-by-belgiumdenmark-finland-france-germany-greece-ireland-italy-luxembourg-the-netherlands-portugal-spain-

sweden?fbclid=IwAR28gAL0zRZSQ_GTn2HevGCZQYrPe1GbOId9jYpE8ktNE5taYS9lvhwgCTI (дата обращения: 21.09.2020).

${ }^{3}$ Шишелина Л.Н. Вишеградские страны: ответственность государства в борьбе с пандемией // Аналитические $\begin{array}{lllllll}\text { записки ИЕ } & \text { РAH. } & \text { №11, } 2020 & \text { (№194). } & \text { С. } & 2 . & \text { URL: }\end{array}$ http://www.instituteofeurope.ru/images/uploads/analitika/2020/an194.pdf (дата обращения: 21.09.2020).

${ }^{4}$ Шишелина Л.Н. Последствия пандемии для центральноевропейской политики и экономики // Аналитические записки ИЕ РАН. №24, 2020 (№207). URL: http://www.instituteofeurope.ru/images/uploads/analitika/2020/an207.pdf (дата обращения: 21.09.2020).
} 
В сентябре 2020 г. количество заболевших резко возросло. С начала месяца оно увеличилось на 24173 человека, что составило около 50\% от всех заболевших с 1 марта 2020 г. На карте распространения заболевания, которую составляет министерство здравоохранения, не осталось «белых» областей с нулевым или незначительным риском заражения. В этой связи чешские власти возобновили работу Центрального кризисного штаба, который был распущен летом после ослабления первой волны пандемии. Эксперты не могут назвать точную причину такого резкого обострения ситуации: объяснения сводятся к увеличению проведенных тест-анализов на наличие коронавируса, видятся в ослаблении ограничительных мер и расширении трансграничных перевозок в летний отпускной период. Каждый из доводов только частично позволяет понять причины настоящего положения вещей.

Премьер-министр А. Бабиш в обращении по центральному телеканалу страны признал допущенные правительством и им лично ошибки в борьбе с пандемией. Он отметил, что послабления, сделанные летом под воздействием «весенних побед», оказались пагубными и привели к росту заболеваемости. В то же время он отметил, что в нынешних условиях правящий кабинет не будет вводить чрезвычайное положение, стараясь найти баланс между охраной здоровья населения и нормальным функционированием экономики.

Подобное развитие событий имело не только эпидемиологические, но и политические последствия. Главным стала отставка 21 сентября, за несколько часов до выступления премьера, министра здравоохранения А. Войтеха, выдвиженца от правящей партии АНО. Его работа на этом посту получила неоднозначные оценки. Некоторые эксперты говорили, что ему удалось не допустить широкого распространения инфекции и характеризовали как прогрессивного чиновника, уделяющего большое внимание цифровизации медицины. Другие наоборот говорили о его запоздалой отставке, которая должна была состояться на 8 месяцев раньше. Фактом остается то, что из 17-ти министров здравоохранения независимой Чехии его срок на посту был третьим по продолжительности.

Решение об отставке было вызвано прежде всего желанием, признав неудачу чешской политики в противостоянии COVID-19, предоставить полномочия по стабилизации ситуации профильному специалисту. А. Войтех, несмотря на успешный опыт работы в сфере здравоохранения, по образованию юрист и в ходе пандемии активно советовался с медиками и эпидемиологами. Это стало причиной для нападок со стороны оппозиции, призывавшей привлечь в правительство компетентного человека.

Неудивительно, что преемником стал врач-эпидемиолог Роман Примула, который в самом начале пандемии возглавлял Центральный кризисный штаб по борьбе с коронавирусом. Несомненно, меры, опробованные в начале кризиса, в том числе благодаря его действиям и позиции, способствовали минимизации последствий. Однако личное недопонимание между Войтехом и Примулой привело к выводу последнего из группы специалистов, активно участвовавших в формулировании антикоронавирусной повестки дня.

В то же время Примула был активно задействован в общественных дискуссиях, посещал популярные ток-шоу, давал интервью с критикой министра здравоохранения. Он с самого начала выступал за жесткий вариант национального карантина и призывал использовать меры для его удержания. Говорил о возможном закрытии государственных границ на один или два года; предрекал ещё в марте, что большая часть чехов проведет свои летние 
каникулы на родине; призывал отказаться от активного живого общения и ограничить его небольшим кругом лиц ${ }^{5}$. Несомненно, введение в состав правительства популярного общественного деятеля, чья позиция оказалась более дальновидной, чем у его предшественника, должно было повысить рейтинг правительства А. Бабиша.

Этот шаг носит тактический характер и предпринят накануне очередных муниципальных выборов и довыборов в Сенат (2-3 октября 2020 г.) В обстановке, когда рейтинг правящей партии постепенно падает ${ }^{6}$ из-за общей усталости населения от ее руководства страной и изза начавшейся второй волны пандемии, требовалась перестановка в правительстве. Она могла показать потенциальному электорату гибкость кабинета в решении насущных задач и готовность идти на встречу актуальным требованиям.

Важно понимать специфику предстоящих выборов и текущий состав Сената, верхней палаты парламента ${ }^{7}$ В отличие от нижней палаты он составлен из представителей оппозиционных партий, активно критикующих деятельность нынешнего кабинета ${ }^{8}$. В последние месяцы Сенат стал настоящей трибуной оппозиции. Наглядный пример -позиция его председателя Милоша Выстрчила по статусу Тайваня и его июньская поездка на этот остров, где он выступил в местном парламенте. Эти действия стали демонстрацией несогласия с линией руководства Чехии на признание «политики одного Китая».

Попытки высших должностных лиц предотвратить эти действия, противоречившие внешнеполитическому курсу страны, не дали эффекта. Позиция Выстрчила была раскритикована А. Бабишем, президентом Милошем Земаном и министром иностранных дел Томашем Петржичеком. Неудивительно, что руководство АНО сейчас очень заинтересовано в том, чтобы как можно удачнее выступить на сенатских выборах. В то же время они являются репетицией перед основным голосованием в парламент, которое намечено на осень 2021 г. Не вызывает сомнений, что итоги экзамена по противодействию COVID-19 будут определять расстановку сил в чешской политической жизни.

Отставку А. Войтеха и его замену на популярного врача-эпидемиолога можно рассматривать как «сакральную жертву», которая была принесена для решения двух наиболее актуальных для правящего кабинета задач. Во-первых, был персонально обозначен и наказан «виновник резкого роста числа заболевших». Для А. Бабиша это важно еще и потому, что, как отмечают аналитики, за многими решениями Войтеха стоял сам премьер, который подчас руководствовался не мнением компетентных специалистов, а данными соцопросов. Министр здравоохранения подал заявление об отставке лично. Он сам, без принуждения, взял ответственность за совершенные ошибки на себя, освободив премьера от необходимости принимать какие-то меры. Учитывая, что в первом мартовском чрезвычайном телеобращении по поводу борьбы с пандемией А. Бабиш говорил, что «несет личную политическую ответственность за все вводимые меры», желание премьера найти «виновного», который бы сознался в содеянном, было понятно.

5 Zdravotnictví povede Prymula. Př́sný epidemiolog i kritik Vojtěcha. Idnes.cz. 21.09.2020. URL: https://www.idnes.cz/zpravy/domaci/roman-prymula-profil-namestek-ministerstva-zdravotnictvi-vladni-zmocnenecpro-vedu-a-vyzkum.A200921_084606_domaci_lre (дата обращения: 21.09.2020).

6 За последние три месяца рейтинг АНО снизился на 4,5\%, достигнув показателя в 27,5\%. URL: https://zpravy.aktualne.cz/pruzkum-verejneho-mineni/l i:keyword:24911/

7 Центральная Европа: политический портрет на фоне 100-летия / под ред. Л.Н. Шишелиной, М.В. Ведерникова. М., 2018. С. 203-205.

${ }^{8}$ Из 81 сенатора только 7 примыкают к движению АНО. 
Во-вторых, что парадоксально, были выполнены просьбы оппозиции, которая выступала за снятие с должности Войтеха ещё весной, когда приводились доводы противоположного плана, касающиеся нарушения прав человека и ограничения свобод из-за слишком строгих запретов. Таким образом, сейчас в глазах электората кабинет Бабиша выглядит надежным и готовым нести ответственность за совершенные ошибки. В свою очередь, оппозиция лишилась козыря, которым ранее удачно пользовалась.

Политическое решение не должно сказаться на эффективности мер по ликвидации вспышки коронавирусной инфекции. Можно предсказать дальнейшее усиление ограничительных и профилактических мер, которые уже постепенно начали вводиться с 18 сентября9. В то же время вряд ли стоит ожидать повторного закрытия границ, прекращения авиаперелетов внутри ЕС и введения чрезвычайного положения, поскольку, как показали предшествующие события, экономический эффект от этих действий может быть куда более разрушительным, чем медицинские последствия пандемии. Выработанные за полгода методы распознавания и лечения болезни, несомненно, будут способствовать недопущению роста летальных исходов.

\section{Рекомендации}

России важно учитывать опыт Чехии: её пример показывает, что отказ от мер предосторожности после первой волны пандемии ведет к резкому росту количества заболевших. Поскольку экономические издержки пандемии могут быть куда более серьезными для общества, нежели её медицинские последствия, важен сбалансированный подход к сдерживанию распространения инфекции. Необходима работа с населением, выработка у него ответственного отношения к мерам предупреждения коронавируса.

Для повышения популярности способов предотвращения распространения COVID-19 стоит рекомендовать официальным лицам, часто выступающим в телевизионных СМИ, появляться в кадре в средствах индивидуальной защиты (масках, перчатках и т.д.) для создания в общественном сознании понимания важности их применения в повседневной жизни. Пример Чехии, официальные представители которой постоянно появляются на публике в масках с национальной символикой, можно считать положительным, поскольку во время первой волны пандемии население восприняло эту меру как обязательную: ей следовали все слои общества, в том числе и представители власти.

Сроки завершения пандемии не ясны, поэтому российским органам власти и иным институтам, планировавшим проведение мероприятий с чешской стороной, стоит перевести их в онлайн формат. В то же время важно учитывать манипулятивный потенциал «ковидной» тематики, готовность политических сил использовать ее для решения своих задач. В этой связи властям необходимо оперативно информировать граждан о мерах поддержки, темпах распространения инфекции, пресекать тиражирование недостоверных слухов, вести открытый диалог с населением.

Abstract. On September 21, 2020, Czech Minister of Health A. Voitech resigned, following the sharp increase of detected COVID-19 cases. This measure was caused by the desire of the country's PM to find a

\footnotetext{
${ }^{9}$ Mimořádná opatření - co aktuálně platí. Vlada.cz. URL: https://www.vlada.cz/cz/epidemie-koronaviru/duleziteinformace/mimoradna-opatreni-_-co-aktualne-plati-180234/ (дата обращения: 21.09.2020).
} 
sacrificial goat. Besides, it was one of the elements of current election campaign for municipal authorities and the Senate. Prime Minister's movement ANO, which previously was not able to successfully perform in those elections, is interested in higher support from voters. The resignation of Voitech was designed to keep the positive image of Babiš government, to show its readiness to compromise and listen to opinions of both the opposition and the population in general.

Key words: Coronacrisis, pandemic, Czech Republic, Central Europe, A. Babǐs, A. Vojtech.

Дата выпуска: 28 сентября 2020 года. 